\title{
Financial management of insurance companies in the context of the new regime Solvency II
}

\author{
Costin ISTRATE \\ The Bucharest University of Economic Studies, Bucharest, Romania \\ istrate_costin@yahoo.com \\ Dumitru BADEA \\ The Bucharest University of Economic Studies, Bucharest, Romania \\ dgbadea@gmail.com
}

\begin{abstract}
The new solvency regime Solvency II represents a solid and harmonized prudential framework applicable by insurance companies in the European area. Solvency II was implemented in the European Union by adopting Directives 2009/138/EC respectively 2014/51/EU, replacing existing directives regulating solvency former regime, known as Solvency I. Thus, the new European legislation in insurance, applicable from 1 January 2016, was aimed at unifying the main European insurance market and ensuring consumer protection. The responsible authority at EU level with the implementation of the new solvency regime is EIOPA - European Insurance and Occupational Pensions Authority, which dealt in previous periods of testing the European market insurance through organizing quantitative impact studies (last exercise - QIS5, organized in 2011). The main standards derived from Solvency II and also the new IFRS accounting provisions, intended to increase the transparency of risk management and investment, in order to pricing insurance products and profitability of the different classes of insurance rates. Solvency II brings both challenges and opportunities for companies, changing the concept of building protection programs for insured and generating additional concerns about capital requirements in the determination of own funds (basic, auxiliary and surplus) that can be used to meet this requirement. Also estimate realistic and prudent risk assumed by insurance contracts concluded transposed to the insurance companies by recording every technical reserves represent a very important element in order to establish an optimal balance of financial resources. Given the significant overlap between IFRS and Solvency II, insurers will have to improve disclosure requirements of additional information and adjust planning and forecasting. All these measures will increase the efficiency of financial management, a series of operational measures and by providing documented and tested processes. Also, increasing volatility related to financial results will cause insurance companies to deliver predictable results, a process that will produce changes in the financial management optics.
\end{abstract}

Keywords: Solvency II, financial management, insurance companies, IFRS.

\section{Introduction}

Solvency II in force from early 2016 in the European insurance sector represented a step forward for the industry, thus establishing a stable, harmonized and consistent with the new economic and social realities. The process of adoption and implementation started since 1997 due to concerns on the part of EU supervisory bodies to introduce new parameters for assessing the solvency of insurance proposals taken by the European Commission in the launch process of Solvency II in 2001, its purpose was to formalize by issuing directives $2009 / 138 / \mathrm{EC}$ or $2014 / 51 / \mathrm{EU}$, which replaced the existing directives that regulated the former solvency regime, known as Solvency I, valid since 1973. 
Solvency II project, conducted over 15 years, benefited from the support and supervision of the new institutions created for this purpose at European level. The entity originally created, CEIOPS - Committee of European Insurance and Occupational Pensions Supervisors, since 2003 by the European Commission, was composed of representatives of supervisory authorities in the insurance and private pensions. CEIOPS has been operating until 2010, the main points developed in the Solvency II process (Insurance ERM, 2015) is presented below:

- 2003 - The „Internal control report for insurance companies” is issued by the Working Group in Madrid, which proposed the establishment of principles for insurers and supervisors, in the implementation or evaluation of internal control systems.

- 2004/2005 - European Commission seek advice and also consultancy from CEIOPS about developments on a new solvency system (Solvency II) for companies that practice life and non-life insurance and reinsurance companies.

- 2006/2010 - CEIOPS launched Quantitative Impact Studies (QIS), publishing the results in the annual reports (EIOPA Publications, 2006-2011), as follows:

- QIS 1 - over 150 life insurance companies, 190 non-life insurance companies and four reinsurance companies, which transmitted the data calculated for the period corresponding to the 2004 financial year by 19 national supervisory authorities in the insurance field. The major conclusion of that study was that the best estimates of technical reserves calculated were lower than levels recorded. On the other hand, the problems identified were: insufficient data necessary study for the treatment of difficulty margins risk, financial risk and accounting for reinsurance treaties.

- QIS 2 - attended by 514 insurance companies in 23 European countries, generally with a market share of over $50 \%$ nationwide. The results were the following: general technical reserves have declined, while capital requirements and available capital also increased. The problems identified were related to the large number of correlations linked to market risk component, particularly between equity and property and between equity and interest rates.

- $\quad$ QIS 3 - attended by 1,027 insurance companies in 28 European countries, covering an overall market share of over $60 \%$. The exercise included a chapter for the financial impact and also a comparison with the Solvency I regime, the results showing that technical reserves tended to decrease, while in terms of the Minimum Capital Requirement (MCR), where most companies (98\%) there was no need for capital increase in order to achieve this level. An important point was the assessment of assets and liabilities balance and in particular the principle of asset valuation, which has proved in the case of investments that they are generally valued correctly at market value or in accordance with IFRS.

- $\quad$ QIS 4 - 1412 insurance companies was participated in belonging to all the 30 member states from EEA - European Economic Area, the participation rate increasing compared to the previous year by 37\%, while the participation rate of small companies insurance increased by $58 \%$. The test results showed that $98.8 \%$ of participating companies have managed to cover the (MCR), while $11 \%$ failed to meet the Solvency Capital Requirements (SCR), especially in large companies (13.2\% ) and non-life insurance companies (11.2\%). 
Starting 1 January 2011, CEIOPS is replaced by a new institution: EIOPA - European Insurance and Occupational Pensions Authority, under the jurisdiction of the European Union, which is one of three European Supervisory Authorities (with ESMA and EBA), part of European System of Financial Supervision. Meanwhile, the text of Directive 2009/138/EC of the European Parliament and of the Council of 25 November 2009 on the taking up and pursuit of the business of Insurance and Reinsurance (Solvency II) is published in the Official Journal of the European Union.

On March 14, 2011 EIOPA published the related report of the fifth Quantitative Impact Study (QIS 5) for Solvency II, which is otherwise the last exercise conducted before adopting the new solvency regime, the results being presented below:

- All 30 EEA member countries were represented by participation in the study of 2,520 insurance and reinsurance companies, also representing a total of 167 groups of insurance-reinsurance;

- $95 \%$ of technical reserves and $85 \%$ of insurance premiums were covered by this test;

- Financial position of the European insurance industry, evaluated on capital requirements calculated in accordance with the new solvency remained at a comfortable level, totaling EUR 359 billion, representing eligible own funds in excess of surveillance requirements;

- Compared to the former regime Solvency I, for groups of insurance-reinsurance that use consolidation method of accounting in the standard formula, there was a reduction of surplus funds in the amount of about 86 billion euro (43\%, from 200 billion euro to 114 billion).

- The sum of all the risks calculated based on SCR was about 1.300 billion euro and in general, the main risks identified are:

- $\quad$ sub-risks market related: equity and interest rates;

- $\quad$ sub-risks related to non-life insurance underwriting: the risk of premiums and reserves and the risk of catastrophe.

- 15\% of participants failed to cover the SCR, and 9\% of participants covered $75 \%$ or less than the calculated level of SCR; also, 5\% of participants failed to cover the MCR, which requires intervention supervisor, meaning the withdrawal of the operating license.

EIOPA has continued the sustained activity, putting in the period 2012-2015 in debate issues related technical Solvency II regime and also publishing new preparatory guides and consultation papers. It should also be mentioned the adoption by the European Parliament during this period, in March 2014, of the Omnibus II Directive which includes adaptations applicable to the sectors of insurance and securities (Omnibus I Directive covered issues related to the banking industry and asset management). This directive established, besides the necessary adjustments for adopting Solvency II, also the date of the implementation of this regime starting with 1 January 2016.

The main research objective is to demonstrate that, taking account of the increasing of risk management importance, the complexity of financial products and also the recent financial crisis effects, the new regime Solvency II will change the financial management optics.

At the moment, supervisory challenges are divided in two main functions: management of systemic risk and day-to-day supervision. In the meantime, the insurance companies are vulnerable to market risks - due to the current low interest rate, which 
represent a source of systemic risk - which could determinate in the future a tough cooperation with the supervisory authorities regarding the exchange of information and coordinated actions (Schoenmaker, 2016).

The necessary changes in investment strategy, as part of the financial management, needs to be done by European insurance companies starting with the hypothesis that the actual structure of the balance sheets, meaning the assets and liabilities components are not calibrated with the new requirements of the global insurance and financial markets.

\section{Treatment of IFRS standards and Solvency II}

Directive 2009/138/EC, which was adopted and implemented new solvency in the insurance field, has regulated general directions (Official Journal of the European Union, 2009) regarding: access and performance, supervision of groups, reorganization and liquidation of insurance companies.

Also, in order to carry on insurance business, reinsurance, as well as calculating solvency capital requirements, the directive established by regulations on new rules:

- Balance sheet valuation of assets and liabilities;

- Technical reserves calculation and recording;

- Determination, classification and eligibility of own funds;

- Investment.

Measuring assets and liabilities balance sheet is carried at the amount that could be traded / transferred / settled related items between stakeholders, voluntarily and knowingly, in objective conditions and normal competition.

The amount of technical reserves (VRT), calculated in a prudent, reliable and objective manner, consists of the average of future cash flows, weighted by the probabilities of achievement (BE - best estimate) and of the risk margin (MR) - in order to honor the obligations of insurance-reinsurance:

$$
\mathrm{VRT}=\mathrm{BE}+\mathrm{MR}
$$

The new provisions establish the calculation of own funds of insurance companies as follows:

- Equity base (FPB) - composed of surplus assets over liabilities and of subordinated liabilities;

- Ancillary own funds (FPA) - consisting of equity, guarantees and commitments legally binding;

- Surplus funds (FSP) - accumulated profits for clients and beneficiaries.

Equity component is represented by the following formula:

$$
\mathrm{FP}=\mathrm{FPA}+\mathrm{FPB}
$$

The importance of determining the own funds of insurance companies, resides in the classification of these funds based on tiers, as follows:

- Funds rank 1 (R1) - including the FPB and FSP available and priority;

- Funds rank 2 (R2) - including the FPB and FPA due priority;

- Funds rank 3 (R3) - the remaining funds.

Consequently, the new regulations had an impact both on the valuation of balance sheet items of insurance companies, reinsurance, crossing it in terms of operational and functional with the accounting for those items and also how to exercise financial management. 
Accounting treatments and modalities of financial reporting in the insurance industry have experienced in the last decade methodological development unprecedented level with the adoption by those companies of accounting standards (IAS - International Accounting Standard) and also the financial reporting standards (IFRS - International Financial Reporting Standards). These standards are a set of rules published as standard by an institution - IFRS Foundation - based in London, UK, which brings together two other entities: IASB (International Accounting Standard Board) - Board responsible for issuing the International Accounting Standards and IFRS Interpretations Committee. Currently, the Foundation has evaluated the use of IFRS accounting standards by 125 of the 149 jurisdictions (84\%), being generally adopted by listed companies, banks, financial and insurance institutions. In Europe, 43 jurisdictions have adopted the IAS and IFRS, representing 29\% globally (IFRS Foundation, 2017).

The main concerns standard insurance and reinsurance market is represented by IFRS 4 - Insurance Contracts, adopted in March 2004 by the IASB (IFRS, IFRS Foundation, 2013). The standard applies to all insurance and reinsurance contracts that the entity issues and reinsurance contracts that it owns and provides:

- Conduct tests as follows:

- $\quad$ test for adequacy of recognized insurance liabilities relating to contracts;

- impairment test for reinsurance assets associated with the contract.

- Presentation of information to help users understand the value of the insurer's financial statements arising from insurance contracts and the nature and extent of risks arising from insurance contracts.

Regarding the adequacy test debt, insurers must assess at the end of each reporting period whether debt related to insurance contracts recognized are adequate, using current estimates of future cash flows related to insurance contracts, and if the assessment shows that the carrying value of debt associated insurance (minus deferred acquisition costs and related intangible assets) is inadequate, the entire deficiency shall be recognized in profit or loss.

Also, IFRS 4 requires an insurer to disclose liabilities associated with insurance contracts without offsetting them by assets associated reinsurance contract related prohibiting reserves for possible damages from contracts that did not exist at the end of the period (such as reserves for catastrophe and equalization) .

Also, some insurance contracts contain both an insurance component and a deposit component; according to the IFRS 4, an insurer is required or permitted to separate the two components.

Consequently, the application by European insurance companies accounting standards - especially standard IFRS4, simultaneously with the adoption from 1 January 2016, the new regime Solvency II will lead those companies to different treatment of managers insurance contracts issued to managing financial assets available, since the components separations front investment and deposit insurance contracts - IFRS 4 and also imposed the classification imposed by Solvency II own funds - in order to meet capital requirements.

Applying IFRS standards will ensure a unified and harmonized data and information, financial accounting, recording similarities to the method of calculating the items balance sheet required by the adoption of Solvency II, for example the consideration of future cash 
flows, calculated both within IFRS 4 - in order to carry out the liability adequacy test - and within Solvency II - in order to calculate technical provisions.

\section{New optical of the financial management}

Implementation of the European insurance market and also in parallel adoption of IFRS and Solvency II regime to the new financial year starting in 2016, represents a new challenge for the financial management function in the European insurance-reinsurance companies.

Eligibility conditions and limitations imposed by Solvency II own funds mentioned above, namely: (CST);

- Common Equity Rank 1 (FP_R1) must be greater than one third of the total equity

- Common Equity Rank 3 (FP_R3) must be less than a third of the total equity (TFP), will determine a financial management function depending on solvency capital requirements, since the method of calculating presented below:

MCR = FPB_R1 > 1/2 x TFPB, where:

- MCR: Minimum Capital Requirements;

- FPB_R1 = common equity rank 1 basis;

- $\mathrm{TFPB}=$ total equity base.

$\Sigma \mathrm{FP} \mathrm{SCR}=(\mathrm{R} 1+\mathrm{R} 2+\mathrm{R} 3)$, where:

- SCR: Solvency Capital Requirement;

- $\Sigma \mathrm{FP}(\mathrm{R} 1+\mathrm{R} 2+\mathrm{R} 3)$ = total equity ranks 1, 2 and 3 .

Thus, one can establish the optimal structure of own funds at the level of each insurance company, presented as follows:

Table 1. Structure of own funds under Solvency II requirements

\begin{tabular}{|c|c|c|c|c|c|}
\hline \multirow{4}{*}{$\begin{array}{c}\text { Rank } \\
1\end{array}$} & \multicolumn{2}{|c|}{ FUNDS AVAILABLE AND PRIORITY } & $\begin{array}{l}\text { LIMITATIONS } \\
\text { OF }\end{array}$ & MCR & $\begin{array}{l}\text { SC } \\
\text { R }\end{array}$ \\
\hline & SURPLUS assets over liabilities & EQUITY BASE & \multirow{3}{*}{$33.33 \%$} & \multirow{2}{*}{$\mathbf{5 0 \%}$} & \multirow{11}{*}{$\begin{array}{l}10 \\
0 \%\end{array}$} \\
\hline & SUBORDINATED DEBT & FUNDS & & & \\
\hline & $\begin{array}{l}\text { BENEFICIARIES AND ACCUMULATED } \\
\text { PROFITS FOR CLIENTS }\end{array}$ & SURPLUS FUNDS & & \multirow{9}{*}{$50 \%$} & \\
\hline \multirow{7}{*}{$\begin{array}{c}\text { Rank } \\
2\end{array}$} & \multicolumn{2}{|c|}{$\begin{array}{l}\text { FUNDING PRIORITIES MATURITY } \\
\end{array}$} & \multirow{7}{*}{$33.33 \%$} & & \\
\hline & SURPLUS assets over liabilities & EQUITY BASE & & & \\
\hline & SUBORDINATED DEBT & FUNDS & & & \\
\hline & $\begin{array}{l}\text { BENEFICIARIES AND ACCUMULATED } \\
\text { PROFITS FOR CLIENTS }\end{array}$ & SURPLUS FUNDS & & & \\
\hline & SOCIAL CAPITAL & \multirow{3}{*}{$\begin{array}{l}\text { ANCILLARY } \\
\text { OWN FUNDS }\end{array}$} & & & \\
\hline & GUARANTEES & & & & \\
\hline & LEGAL OBLIGATIONS AND COMMITMENTS & & & & \\
\hline $\begin{array}{c}\text { Rank } \\
3\end{array}$ & \multicolumn{2}{|l|}{ OTHER FUNDS } & $33.33 \%$ & & \\
\hline
\end{tabular}

Source: Author's analysis based on DIRECTIVE 2009/138/EC, Official Journal of the European Union (2009).

Monitor surplus assets over liabilities can be achieved from an operational perspective by taking practical function of assets and liabilities management (ALM - AssetLiability Management). According SOA (Society of Actuaries), ALM can be defined as a continuous process of formulation, implementation, monitoring and revising strategies 
related to assets and liabilities of an entity in order to achieve financial objectives, taking into account the risks and constraints to which it is subject to the respective organization.

Due to a proper risk management, the risks can be diversified and also reduced by hedging operations (Constantinescu, 2005), taking account the economic environment and also the competition forces on the insurance-reinsurance market.

Consequently, the management function is subject to balance sheet assets and liabilities on the one hand the pressures typology identified risks and on the other side constraints related to maintaining an optimal level of solvency, a graphic example is shown below:

Table 2. Influence of risk and equity on the balance sheet assets and liabilities to determine the SCR under Solvency II

\begin{tabular}{|c|c|c|c|c|c|}
\hline RISKS & ASSETS & LIABILITIES & FUNDS & \multicolumn{2}{|c|}{ SOLVENCY II } \\
\hline \multirow{5}{*}{$\begin{array}{c}\text { MARKET } \\
\text { AND } \\
\text { COUNTERPARTY }\end{array}$} & $\begin{array}{l}\text { FINANCIAL } \\
\text { INVESTMENTS: }\end{array}$ & \multirow{3}{*}{ SHARE CAPITAL } & \multirow{3}{*}{ ANCILLARY } & & \multirow{10}{*}{$S C R$} \\
\hline & bonds & & & & \\
\hline & Bank deposits & & & & \\
\hline & shares held & & & & \\
\hline & real estate & PRUFTTS & & & \\
\hline \multirow{5}{*}{$\begin{array}{c}\text { SUBSCRIPTION, } \\
\text { COUNTERPARTY } \\
\text { AND } \\
\text { OPERATIONAL }\end{array}$} & $\begin{array}{l}\text { RECEIVABLES FROM } \\
\text { INSURANCE }\end{array}$ & $\begin{array}{l}\text { INSURANCE } \\
\text { PROVISIONS }\end{array}$ & \multirow{5}{*}{ BASE } & \multirow{5}{*}{$M C R$} & \\
\hline & \multirow{4}{*}{$\begin{array}{l}\text { RESERVES / } \\
\text { REINSURANCE }\end{array}$} & $\begin{array}{c}\text { DEBT / } \\
\text { REINSURANCE }\end{array}$ & & & \\
\hline & & $\begin{array}{l}\text { TECHNICAL } \\
\text { RESERVES: }\end{array}$ & & & \\
\hline & & best estimates & & & \\
\hline & & the risk margin & & & \\
\hline
\end{tabular}

Source: Author's analysis based on DIRECTIVE 2009/138/EC, Official Journal of the European Union (2009).

European insurance industry is the largest market in the world (according to official data recorded in 2015), with a share of $32 \%$ of the global market, followed by the North American market with a market share of $31 \%$ and market Asian with a share of $30 \%$.

Of the total insurance premiums written in Europe by nearly 3,700 companies, amounting to 1.200 billion euro, approximately $40 \%$ are underwritten by 10 major European groups (Insurance Europe, 2016), as follows:

Table 3. Situation top 10 largest European insurance groups based on gross premiums written in

\begin{tabular}{|l|l|c|c|c|}
\hline \multicolumn{1}{|c|}{ GROUP } & COUNTRY & $\begin{array}{c}\text { Premiums written } \\
\text { (billion euro) }\end{array}$ & $\begin{array}{c}\text { MARKET } \\
\text { SHARE }\end{array}$ & $\begin{array}{c}\text { SOLVENCY } \\
\text { MARGIN }\end{array}$ \\
\hline AXA & FRANCE & 92 & $19 \%$ & $2.46 \%$ \\
\hline ALLIANZ & GERMANY & 77 & $16 \%$ & $2.00 \%$ \\
\hline GENERALI & ITALY & 74 & $15 \%$ & $1.64 \%$ \\
\hline
\end{tabular}

DOI: 10.1515/picbe-2017-0067, pp. 625-636, ISSN 2558-9652| Proceedings of the $11^{\text {th }}$ International Conference on Business Excellence 


\begin{tabular}{|l|l|c|c|c|}
\hline PRUDENTIAL & UK & 51 & $11 \%$ & $2.50 \%$ \\
\hline ZURICH & SWITZERLAND & 44 & $9 \%$ & $2.03 \%$ \\
\hline TALANX & GERMANY & 32 & $7 \%$ & $2.19 \%$ \\
\hline CNP ASSURANCES & FRANCE & 31 & $6 \%$ & $1.18 \%$ \\
\hline $\begin{array}{l}\text { CREDIT AGRICOLE } \\
\text { ASSURANCES }\end{array}$ & FRANCE & 30 & $6 \%$ & $1.19 \%$ \\
\hline AVIVA & UK & 30 & $6 \%$ & $2.20 \%$ \\
\hline MAPFRE & SPAIN & $\mathbf{4 8 3}$ & $5 \%$ & $2.55 \%$ \\
\hline \multicolumn{2}{|l|}{ TOTAL } & $\mathbf{1 0 0 \%}$ & \\
\end{tabular}

PICBE | 632

The analysis of data recorded by the major insurance groups listed above stands on one side underwritings volume growth of 7.8\%, from 449 billion euro in 2014 to 483 billion euro in 2015 and on the strong market concentration elsewhere around the first 3 insurance companies: AXA, Allianz and Generali, meeting the total market share of 50\%.

The insurance industry is the largest institutional investor in Europe, with a value of around 9,800 billion euro of assets invested in the economy in 2015 , up $1.7 \%$ compared to 2014. The structure of the investment portfolio of the European insurers is represented further (IAIS, 2016):

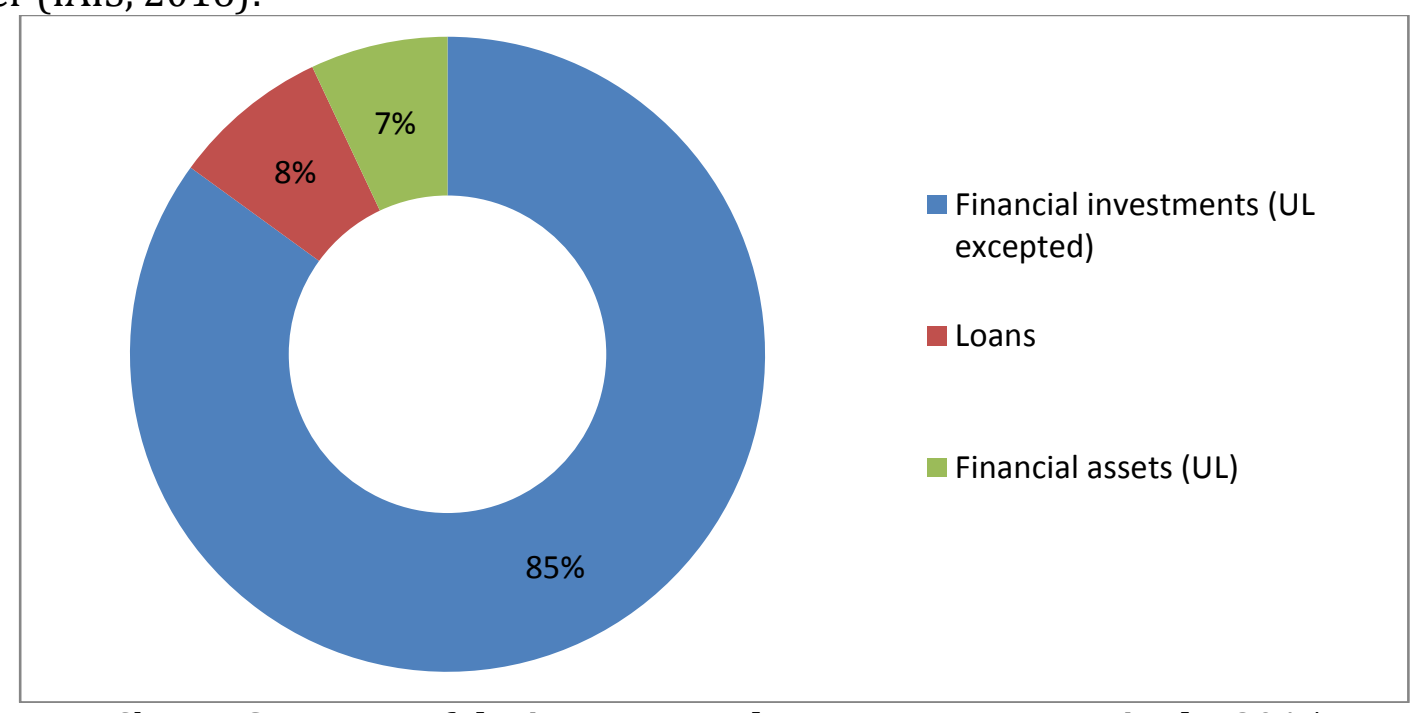

Chart 1. Structure of the investments by European companies by 2015

Source: IAIS, 2016. 


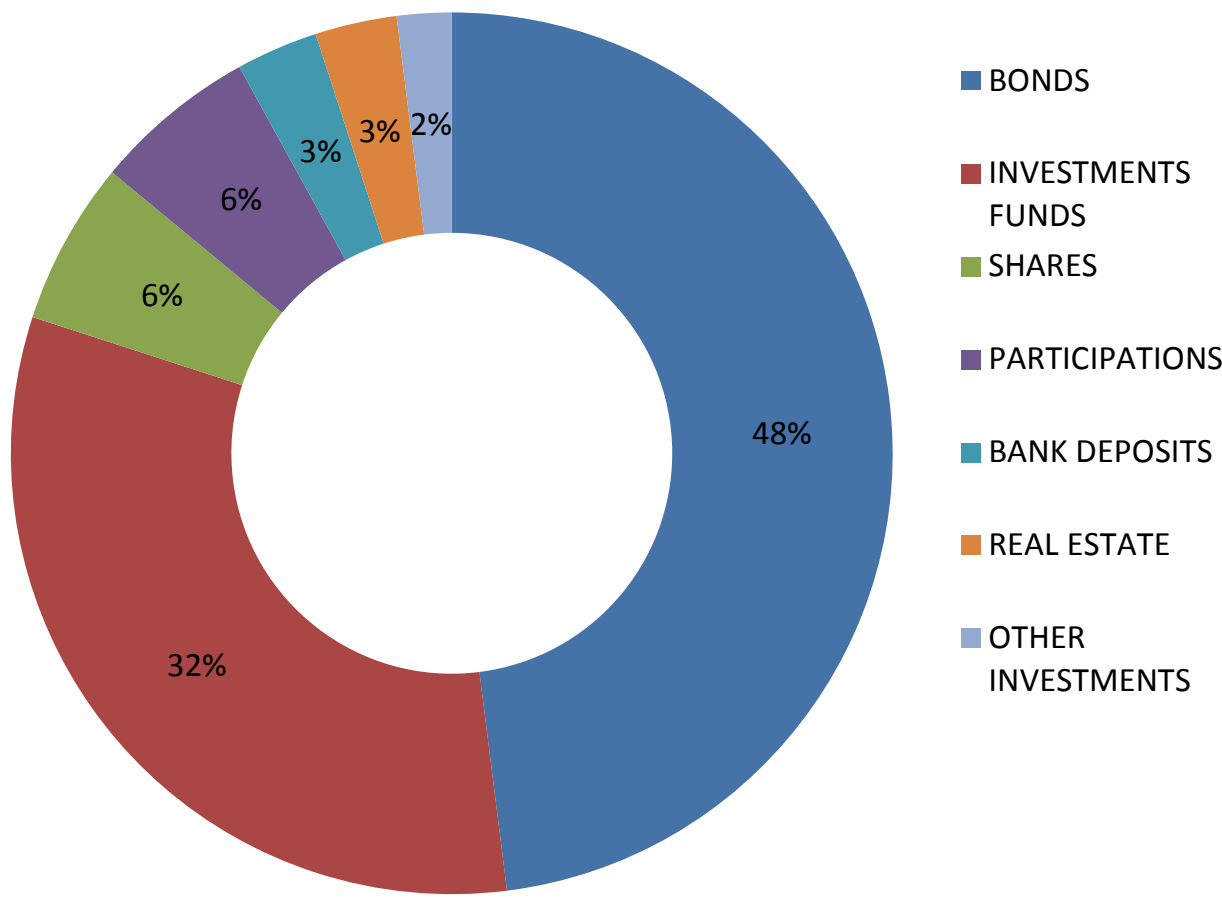

PICBE | 633

\section{Chart 2. Structure of financial investments (excluding unit-linked) related to European companies by 2015}

Source: IAIS, 2016.

Given the degree of concentration of major European insurance market around the three insurance groups AXA, Allianz and Generali, were collected data related balance sheet items mentioned companies as follows:

Table 4. Situation on balance sheet items related to the first three European groups at the end of 2015 (billion euro)

\begin{tabular}{|l|r|r|r|r|r|r|}
\hline \multicolumn{1}{|c|}{ INSURANCE GROUP } & \multicolumn{2}{|c|}{ AXA } & \multicolumn{2}{c|}{ ALLIANZ } & \multicolumn{2}{c|}{ GENERALI } \\
\hline \multicolumn{1}{|c|}{ BALANCE SHEET } & AMOUNT & \multicolumn{1}{c|}{$\%$} & AMOUNT & $\%$ & AMOUNT & \multicolumn{1}{c|}{$\%$} \\
\hline \multicolumn{1}{|c|}{ TOTAL ASSETS, WHICH: } & $\mathbf{8 8 7}$ & $\mathbf{1 0 0} \%$ & $\mathbf{8 4 9}$ & $\mathbf{1 0 0 \%}$ & $\mathbf{5 0 1}$ & $\mathbf{1 0 0 \%}$ \\
\hline INVESTMENTS & 500 & $56 \%$ & 509 & $60 \%$ & 372 & $74 \%$ \\
\hline FINANCIAL ASSETS (UL) & 195 & $22 \%$ & 106 & $12 \%$ & 75 & $15 \%$ \\
\hline BANK ACCOUNTS AND DEPOSITS & 26 & $3 \%$ & 15 & $2 \%$ & 9 & $2 \%$ \\
\hline INTANGIBLE ASSETS & 47 & $5 \%$ & 13 & $2 \%$ & 9 & $2 \%$ \\
\hline OTHER ASSETS & 119 & $13 \%$ & 206 & $24 \%$ & 36 & $7 \%$ \\
\hline \multicolumn{1}{|c|}{ Total liabilities, of which: } & $\mathbf{8 8 7}$ & $\mathbf{1 0 0} \%$ & $\mathbf{8 4 9}$ & $\mathbf{1 0 0 \%}$ & $\mathbf{5 0 1}$ & $\mathbf{1 0 0 \%}$ \\
\hline EQUITY & 73 & $8 \%$ & 66 & $8 \%$ & 25 & $5 \%$ \\
\hline $\begin{array}{l}\text { RESERVES INSURANCE AND } \\
\text { INVESTMENT }\end{array}$ & 675 & $76 \%$ & 558 & $66 \%$ & 405 & $81 \%$ \\
\hline FINANCIAL DEBTS & 79 & $9 \%$ & 106 & $12 \%$ & 50 & $10 \%$ \\
\hline OTHER DEBTS & 60 & $7 \%$ & 119 & $14 \%$ & 21 & $4 \%$ \\
\hline
\end{tabular}

Source: Authors' own research on companies audited annual reports for 2015.

From the analysis of the data presented results the following: 
- Total investments of the asset side occupies a overwhelming position: between $56 \%$ and $74 \%$ of assets, which demonstrates their concern for an investment policy permanent and also constant, in order to cover reserve holdings total liabilities for future liabilities arising from activities insurance and investment as a share situated between $66 \%$ and $81 \%$ of liabilities;

- Stands also share financial assets of unit-linked type (UL) asset side: between $12 \%$ and 22\%; UL products are investment products usually attached to life insurance policies, which provide customers develop an investment portfolio - against payment of a premium investment - until the expiry of the insurance; products do not have a guaranteed return, however, are different products depending on the client's risk profile, thus requiring careful management and permanent through a specialized financial management and investment; correspondence of liabilities for this type of products is recorded by some companies in the reserves, and by others in the financial debt - which as a share between $9 \%$ and $12 \%$ of liabilities;

- A surprisingly low level of $2 \%-3 \%$ of the activity is in demand deposits and bank deposits; intended mainly to ensure a sufficient level of liquidity, availability of bank must cover the short and medium term damage payments, commissions from insurance, administrative expenses, as well as any debts to partners as a result of ceding reinsurance; in return, other than financial liabilities are situated between $4 \%$ and $14 \%$ and financial liabilities, between 9 and 12\%; the cumulative pressure on bank liquidity is higher than one, considering the average share of total debt (19\% of liabilities), compared to the average share of deposits banks ( $2 \%$ of assets);

- Last but not least, the equity owned by the three companies at levels between $5 \%$ and $8 \%$ of liabilities, a level quite low, which also explains and pressure on capital and profits gained by the new regime Solvency II.

Consequently, given the foregoing, new optics of the financial management in insurance should take into account the following aspects:

- Establishment of mechanisms at the level of financial management - which takes into account future cash flows generated by the insurance aspect taken into account Solvency II and IFRS 4 - by which to settle permanently optimal levels of investment and that availability of bank;

- Creation of specialized investment departments in the financial management function - change driven by trend growth and product diversification of UL;

- Reduction of financial debt and other debts through a modern financial management in the management of receivables.

A proper financial management in insurance companies should include capital management actions under the investment strategy, which beside ALM techniques or using the derivatives contracts in hedging transactions, can include the following (Clarke, Mitchell, Phelan in Milliman Research Report, 2014):

- Rebalancing investment portfolios;

- UL matching or hedging the annual management charge.

Also, due to the market practice, where the large insurance groups developed integrated asset and risk management systems at group level, offering for the local branches internal consultancy and asset management expertise (Schoenmaker, 2016), the insurance companies needs to make local adaptation of ALM techniques. 


\section{Conclusion}

The structure on the eligibility of own funds imposed by Solvency II, and treatment of financial instruments in general or investment component separation of insurance products for IFRS will generate changes in optics financial management at insurance companies.

The situation presented above, which shows a concentration of investments in the balance sheets of insurance companies exceeding 50\%, demonstrates on the one hand concern the insurance industry in the financial activity and investment, and on the other hand ensuring a stable foundation in order to cover capital requirements imposed by Solvency II regime. However, both these requirements, and the requirements of IFRS standards on transparency and information to end users, will force management insurance companies to increase the quality of portfolio investment, in the sense of providing funds you should not be exposed to excessive market risks.

Although it is an element to degrade related to liquidity, low availability of banking, averaging just $2 \%$ of the balance sheet, it can generate stress conditions of insurance business pressures including covering capital requirements under Solvency II, taking into account of other factors, namely: the low level of equity (between $5 \%$ and $8 \%$ ) and also the high level of debt.

In these conditions, the pressure only on the capital of insurance companies in terms of insolvency in the sense of increasing it (given the financial leverage between reserve and liabilities on the one hand and equity on the other hand), it seems to no longer the only measure to remedy or improve solvency level. Thus, insurers will have to change their optical financial management, primarily by considering the future cash flows generated by the insurance business. Secondly, the creation of specialized functions within financial management, responsible for managing the investments made modern, with the following objectives:

- Specialized management of UL contracts;

- Reduced level of investment in parallel with the increasing level of cash and deposits in banks;

- Increasing transparency and also the frequency of reporting to clients and shareholders.

In conclusion, financial management at insurance companies will increase in importance in the coming period, growth due to both changes imposed by the new regulations on Solvency II and IFRS and also because of the transformation and modernization of the insurance business, by the interdependence of this sector with investment activity.

\section{References}

Insurance ERM (2015). Solvency II timeline. Retrieved from https://www.insuranceerm.com/guides/solvency-ii-timeline.html.

EIOPA Publications (2006-2011). QIS1 - Summary report; QIS2 - Summary Report; CEIOPS' Report on its third Quantitative Impact Study (QIS3) for Solvency II; CEIOPS' Report on its fourth Quantitative Impact Study (QIS4) for Solvency II; EIOPA Report on the fifth Quantitative Impact Study (QIS5) for Solvency II. Retrieved from https://eiopa.europa.eu/Publications. 
Official Journal of the European Union (2009). DIRECTIVE 2009/138/EC OF THE EUROPEAN PARLIAMENT AND OF THE COUNCIL of 25 November 2009 on the taking-up and pursuit of the business of Insurance and Reinsurance (Solvency II). Retrieved from $h t t p: / / e u r-l e x . e u r o p a . e u$.

CECCAR (2013), IFRS. 2013 IFRS Foundation.

IFRS Foundation. (2017). Standards and Interpretations. Retrieved from PICBE|636 http://www.ifrs.org.

Insurance Europe, European Insurance - Key Facts. (2016,). Retrieved from http://www.insuranceeurope.eu.

IAIS, 2015 Global Insurance Market Report (GIMAR). (2016). Retrieved from https://www.iaisweb.org.

AXA GROUP, ANNUAL FINANCIAL REPORT 2015. (2016). Retrieved from https://www.axa.com.

Allianz Group, Annual Report 2015 (2016). Retrieved from https://www.allianz.com.

GENERALI, Annual Integrated Report 2015 (2016). Retrieved from www.generali.com.

Constantinescu, D.A. (2005). Management financiar in asigurari. EDITURA ECONOMICA.

Clarke S., Mitchell S., Phelan E. (2014). Capital management in a Solvency II world. Milliman Research Report, Retrieved from http://www.milliman.com.

Schoenmaker, D. (2016). EUROPEAN INSURANCE UNION AND HOW TO GET THERE. POLICYBRIEF ISSUE 4, Bruegel, DECEMBER 2016. Retrieved from http://bruegel.org.

Society of Actuaries. Professional Actuarial Specialty Guide Asset-Liability Management. (2003). Retrieved from https://www.soa.org. 